\section{Grådighetens pris}

Faglig og redaksjonell kvalitetssikring, tilrettelegging for publisering (produksjon), trykking og distribusjon er kostnader i et tidsskriftregnskap. Men nå er det er lenge siden open access-tidsskriftene viste oss at man verken trenger papir, trykking eller dyr postal distribusjon for å formidle fagfellevurdert forskning på en leservennlig måte. Internett har senket terskelen for å entre publiseringsbransjen, og tidsskrifter med hundreårig tradisjon har måttet se unge utfordrere yppe seg i kampen om både attraktive manus og impaktfaktor. Impaktfaktor er et gjennomsnittsmål for hvor hyppig artikler blir sitert i løpet av et bestemt tidsrom (1).

De nettbaserte tidsskriftene oppsto ikke kun fordi det er blitt så mye enklere å publisere, men også som en reaksjon på at etablerte og anerkjente tidsskrifter ble mindre tilgjengelige. Kommersielle forlagshus spekulerte i leserbetaling og bygde opp høye betalingsmurer rundt produktene. Dette har resultert $i$ at både institusjoner og enkeltpersoner ikke lenger kan abonnere for egen regning (2). Magne Nylenna beskrev open access-bevegelsen som «forskningsformidlingens frihetskamp» da han omtalte den på lederplass her i Tidsskriftet i 2001 (3). Open access-tidsskriftene gir leserne fri tilgang - de er basert på betaling fra forfatterne som ønsker å publisere. I tillegg er gaver fra velgjørere og myndigheter med på å dekke kostnadene.

Annonsene har, sammen med særtrykk og abonnementer, vært et fundament i de tradisjonelle tidsskriftenes inntekter. Selv om tilbyder lenge har kunnet benytte seg av direkte kontakt med kundene i for eksempel brev, har kostnadene knyttet til dette vært høye. Internett endret dette radikalt. Når kostnadene knyttet til trykking og distribusjon forsvant, fikk den annonsebaserte økonomien en sterk utfordrer. Annonsørene kan nå sine kunder nærmest kostnadsfritt på nett. Samtidig svekkes lesernes betalingsvilje av nettbaserte gratisprodukter. Den tradisjonelle publiseringsmodellen har vært en lukrativ virksomhet, men den utfordres nå av digitalisering, Internett og sosiale medier. Det kreves nytenkning og endringsvilje for den som vil overleve. Men er det open access-modellen som kommer til å redde forskningsformidlingen?

Når alle kan publisere - for eksempel i egen blogg - og gjør det, vil også open access-modellen, basert på forfatterbetaling, kunne få det tøft. Under konferansen Science Online i London høsten 2010 diskuterte forskere ved noen av verdens fremste universiteter denne muligheten. Tradisjonell fagfellevurdering før publisering kan erstattes av åpen diskusjon av artikkelen etterpå. Den amerikanske teknologiskribenten Clay Shirky beskriver nettopp dette fenomenet i boken Here comes everybody: «Vi lever i en tidsalder der vi publiserer først og filtrerer senere» (4). Wikipedia er et eksempel på dette. Tekstene i nettleksikonet anses ikke som ferdige, men som del av en pågående prosess. Vi kjenner svakhetene, men det hindrer oss ikke i å bruke det aktivt.

Det som skjer innen akademisk publisering, har paralleller i andre bransjer som også har fått spillereglene fundamentalt endret som følge av ny teknologi. Et godt eksempel er platebransjen. Digitalisering åpnet muligheten for enkel lagring av store mengder musikk. Det ble lett å kopiere og dele musikkfiler. Bransjen opplevde fall i CD-salget og reagerte med å stritte imot teknologien. I stedet for å utnytte den forsøker de å beskytte sine etablerte modeller for distribusjon og prissetting gjennom tiltak mot fildeling og rettssaker mot dem som piratkopierer musikk.
Vi kan tenke på CD-platen som platebransjens tidsskriftutgave. Når lytterne etterspurte enkeltspor, ville bransjen fortsatt selge hele utgaver (plater). Når brukerne ba om lavere pris, siden produktet var blitt digitalt og kostnadene ved å distribuere det minimert, tviholdt bransjen på den etablerte prisstrukturen. Så kom Spotify på banen nesten som musikkbransjens svar på open access-bevegelsen - med gratis musikk, artistene med på laget og muligheter for brukerne til å sette sammen egne spillelister (utgaver). Spotify er en musikktjeneste hvor du laster ned musikken fra nettet (streamer) samtidig som du hører på den. Utvalget er svært bredt og lett tilgjengelig.

I stedet for å jobbe mot teknologien, jobber Spotify med den. De har fått brukerne til å velge dem fremfor piratkopiert musikk. Den prisen brukerne betaler for lovlig lytting, er reklame mellom sangene. Det er denne reklamen, men ikke minst salg av produktet reklamefritt og tilrettelagt for flere plattformer, som gjør at Spotify tjener penger. Artister og plateselskaper har valgt å akseptere lavere inntekter. Spotify skiller seg imidlertid fra open access-bevegelsen på ett viktig punkt: Det er fortsatt lytterne og annonsørene som finansierer tjenesten. Artistene trenger Spotify for å markedsføre musikken sin slik at de kan lokke publikum til konserter, som er blitt viktigere som inntektskilde. På samme måte vil kanskje forfattere trenge tidsskrifter med høy anseelse for å markedsføre og finansiere forskningen sin?

Så hva kan redde tidsskriftene og sikre dem en viktig rolle også i fremtidens forskningsformidling? Avisbransjen har spurt seg det samme, og professor emeritus i journalistikk Philip Meyer mener nøkkelen er kvalitet (5). Hans tese er at kvalitet gir innflytelse og at innflytelse fortsatt er attraktivt for annonsører og lesere. Ved å kompromisse med kvalitetskravene pga. økonomisk press mister man anseelse og innflytelse og taper i kampen med nye publikasjoner uten tilsvarende tradisjoner for kvalitetssikring.

Mens de tradisjonelle tidsskriftene har etablerte kvalitetssikringsrutiner som sitt konkurransefortrinn, har open access-tidsskriftene fleksibel struktur, innovativ produktutvikling og lave produksjonskostnader som sitt. De gamle tidsskriftene utfordres av utgivernes grådighet og mangelen på fleksibilitet i etablerte rutiner, mens de nye utfordres av verdiene i kulturen de selv er en del av, der både kvalitetssikrings- og produktbegrepet er redefinert. Tidsskrifter som klarer å kombinere det beste fra disse to tradisjonene, kan bli den akademiske publiseringsbransjens «spotify».

\section{Stine Bjerkestrand \\ stine.bjerkestrand@legeforeningen.no}

Stine Bjerkestrand (f. 1972) er utviklingsredaktør i Tidsskriftet og cand.mag. med journalistikk, medievitenskap og statsvitenskap i fagkretsen.

\footnotetext{
Litteratur

. Hem E, Ødegaard R. Hvor ofte blir artikkelen sitert? Tidsskr Nor Legeforen 2009; 129: 205

2. Haug C. Fri flyt av ord. Tidsskr Nor Lægeforen 2004; 124: 2733.

3. Nylenna M. Forskningsformidlingens frihetskamp. Tidsskr Nor Lægeforen 2001; 121: 1997

4. Shirky C. Here comes everybody: the power of organizing without organizations New York: Penguin, 2008

5. Meyer P. The vanishing newspaper. Saving journalism in the information age. Columbia, MO: University of Missouri Press, 2004.
} 